\title{
Evaluation of quality factors of bovine and chicken meat marinated with reduced sodium content
}

\author{
Camila Barbosa CARVALHO ${ }^{1 \star}$, Grasiele Scaramal MADRONA², Silvana da Silva CORRADINE ${ }^{1}$, \\ Péricles Martim RECHE ${ }^{3}$, Magali Soares dos Santos POZZA ${ }^{4}$, Ivanor Nunes do PRADO 5
}

\begin{abstract}
In many industrialized countries, including Brazil, sodium intake exceeds the nutritional recommendations. Excessive consumption is associated with hypertension and premature death by cardiovascular diseases. The industry's challenge is to produce products with reduced sodium that are similar to regular products in texture and flavor and consistent with consumers' dietary habits. The present study aimed at substituting 25 and $50 \% \mathrm{NaCl}$ for $\mathrm{KCl}$ in marinated beef and chicken meat with the addition of aromatic herbs and spices. The following microbiological analyses were carried out: macronutrient, chemical composition, and sensorial analysis. The meats showed a reduction in $\mathrm{NaCl}$ contents without any changes in their physical and chemical characteristics, and the products' quality and microbiological safety were maintained. Beef and chicken tenderness was maintained for both treatments. Furthermore, the use of $50 \% \mathrm{KCl}$ did not cause any changes in the products' sensory quality, and the overall acceptance of both types of meat was maintained. Results showed that a reduction by $50 \%$ in the $\mathrm{NaCl}$ contents of marinated meat products with a combination of herbs and spices is possible. Future applications in other meat products and sausages are highly promising.
\end{abstract}

Keywords: beef; spices; herbs; sensory analysis; lipid oxidation; texture.

\section{Introduction}

Meat and meat products are important sources of protein, fat, and other nutrients (BIESALSKI, 2005). In recent years, consumers' demands for safer and higher quality meat and meat products with reduced levels of fat, cholesterol, sodium chloride $(\mathrm{NaCl})$, nitrite, and an improved composition of fatty acid profile and incorporated health-enhancing ingredients have been rapidly increasing worldwide (SCOLLAN et al., 2006; HOCQUETTE et al., 2012). Meat enrichment with bioactive compounds and the effects of meat-based substances on human health have been studied extensively (ZHANG et al., 2010). Consumers' acceptance of functional foods varies widely and depends on their social, economic, geographical, political, cultural, and ethnic backgrounds (JIMÉNEZ-COLMENERO; CARBALLO; COFRADES, 2001).

Different studies have shown that human health risks, such as hypertension, may be related to high $\mathrm{NaCl}$ intake (ELLIOTT et al., 2007), triggering and worsening coronary heart diseases (COOK et al., 2007), stroke occurrences (XIE et al., 1992), and non-cardiovascular diseases (TAREK; GRAHAM, 1996). In fact, approximately $12.8 \%$ of world population's mortality rate may be associated to a non-optimal blood pressure (LAWES et al., 2006). It has been estimated that if global $\mathrm{NaCl}$ intake were reduced at approximately $10 \mathrm{~g} \mathrm{day}^{-1}$, around one quarter of mortality rates caused by coronary heart diseases and one third of deaths by stroke would be prevented. Moreover, a reduction to $3 \mathrm{~g}$ day $^{-1}$ would have relevant additional effects. The long term target for $\mathrm{NaCl}$ intake worldwide should actually be $3 \mathrm{~g} \mathrm{day}^{-1}$ instead of $6 \mathrm{~g}$ day $^{-1}$ (HE; MACGREGOR, 2003).

An efficient and cost-effective way to reduce heart diseases and stroke occurrences is the reduction of $\mathrm{NaCl}$ in food. Consequently, the food industry has been trying to reduce $\mathrm{NaCl}$ in foods by replacing sodium with other substances. However, $\mathrm{NaCl}$ replacement in food is complex, especially in meat products, and therefore it requires a deeper understanding of $\mathrm{NaCl}$ mechanism in meat. In the case of sodium reduction, several ingredients such as potassium, ammonium, calcium, magnesium (CARDOZO, 2004), lithium, in the form of chloride salts, and anions, such as phosphate and glutamate, should be reduced. Potassium chloride $(\mathrm{KCl})$ is a common alternative and a possible substitute for sodium (BECK; JEKLE; BECKER, 2012). Sensory analyses have shown that $20 \%$ of $\mathrm{NaCl}$ may be replaced with $\mathrm{KCl}$ in foods (CARDOZO, 2004). Since the use of $\mathrm{KCl}$ provides a negative taste to the product (BECK; JEKLE; BECKER, 2012), other natural ingredients, including herbs and spices, have been studied as potential sodium reduction and replacement in meat and meat products (CARRARO et al., 2012).

$\mathrm{NaCl}$ cannot obviously be substituted for a single substance. Instead, possible substitutes should be combined in such a way that the meat's taste and quality remain largely preserved.

\section{Received 7/15/2013}

Accepted 10/14/2013 (006164)

${ }^{1}$ Centro de Ciências Agrárias, Universidade Estadual de Maringá - UEM, Av. Colombo, 5790, CEP 87020-900, Maringá, PR, Brasil, e-mail: camilab.carvalho@hotmail.com

2 Departamento de Engenharia de Alimentos, Universidade Estadual de Maringá - UEM, Av. Colombo, 5790, CEP 87020-900, Maringá, PR, Brasil

${ }^{3}$ Departamento de Enfermagem e Saúde Pública, Universidade Estadual de Ponta Grossa - UEPG, Av. Gal Carlos Cavalcanti, 4748, CEP 84030-900, Ponta Grossa, PR, Brasil

${ }^{4}$ Departamento de Zootecnia, Universidade Estadual do Oeste do Paraná - UNIOESTE, Rua Pernambuco, 1777, CEP 85960-000, Marechal Cândido Rondon, PR, Brasil

${ }_{5}^{5}$ Departamento de Zootecnia, Universidade Estadual de Maringá - UEM, Av. Colombo, 5790, CEP 87020-900, Maringá, PR, Brasil

${ }^{*}$ Corresponding author 
Today, the partial substitution of $\mathrm{NaCl}$ for $\mathrm{KCl}$ and the addition of aromatic herbs and spices in meat products have become a promising strategy for the reduction of sodium and for the maintenance of the products' palatability. The present study aims at reducing the sodium content of marinated meats (beef and chicken) by replacing 25 and $50 \% \mathrm{NaCl}$ with KCL and adding herbs and spices while maintaining the product's quality.

\section{Materials and methods}

\subsection{Sample collection}

Six bovine Longissimus dorsi $(\mathrm{LD})$ muscles were obtained from a local abattoir 24 hours after slaughter. The muscles were vacuum-packed and kept at $4{ }^{\circ} \mathrm{C}$. The samples came from 20-month old Aberdeen Angus vs. Nellore bulls raised on the same farm and fed ad libitum a concentrated diet and corn silage. Nine bovine knuckles (Quadriceps femoris) were obtained from the Frigorifico Maria Macia in Campo Mourão, PR, Brazil. Chicken meat (Drumstick and Chicken Breast Fillet) from the same lot was obtained from Frigorifico Frangos Canção in Maringá, PR, Brazil. The samples from each muscle were analyzed in triplicate. Steaks of $2 \mathrm{~cm}$ thickness were cut, vacuum-packed, and kept frozen at $-18{ }^{\circ} \mathrm{C}$ for two months for further analysis. Prior to each analysis, the samples were thawed in a refrigerator at $4{ }^{\circ} \mathrm{C}$ for 24 hours, removed from the vacuum package, individually placed in polystyrene trays $(15.5 \times 21.5$ $\times 2.5 \mathrm{~cm}$ ), and randomly assigned to each treatment group.

Spices and herbs were purchased from a local market in Maringá, PR, Brazil. The following spices were used for the marinades: garlic (Allium sativum), annatto (Bixa orellana), turmeric (Curcuma longa), chilli (Capsicum frutescens), ground pepper (Piper nigrum), oregano (Oreganum vulgare), and marjoram (Oreganum majorana). The reagents were of analytical grade.

\subsection{Samples and marinating process}

Six samples were prepared to determine the effect of substituting $25 \%$ and $50 \%$ of sodium chloride $(\mathrm{NaCl})$ for potassium chloride $(\mathrm{KCl})$ using herbs and spices. Three formulations were prepared for both the bovine and chicken meat, as shown in Table 1.
Herbs and spices accounted for $17 \%$ of the spice formulation used for the two types of marinated bovine and chicken meat.

Marinated meat was formulated with $2 \mathrm{~g}$ of seasoning for $100 \mathrm{~g}$ meat and $20 \mathrm{ml}$ water. The meat was immersed in the marinade so that ingredients would gradually penetrate by diffusion without the application of force for 24 hours at $4{ }^{\circ} \mathrm{C}$ and were then vacuum-packed.

\subsection{Microbiological analyses}

The three samples in the same batch were used in the microbiological, food safety, and product contamination analysis after processing were evaluated for thermo-tolerant coliforms; and Salmonella sp. was determined as proposed by Silva, Junqueira and Silveira (1997).

\subsection{Chemical analysis}

Laboratory analyses of beef were carried out two months after sampling. Meat samples were thawed at $4+1{ }^{\circ} \mathrm{C}$, ground, homogenized, and analyzed in triplicate. Meat moisture and ash contents were determined according to ISO-R-1442 (INTERNATIONAL..., 1997) and ISO-R-936 (INTERNATIONAL..., 1998). Crude protein contents were assessed following ISO-R-937 (INTERNATIONAL..., 1978), and total fat was determined according to ISO-R-1443 (INTERNATIONAL..., 1973) .

The samples were digested using the drying method according to the AOAC (ASSOCIATION..., 1998) for the analysis of their mineral composition. Sodium and potassium were quantified using an AA240FS atomic absorption spectrophotometer (Varian, USA) as mg of mineral per $\mathrm{kg}$ of product using standard solutions and analytical curves.

\section{$2.5 \mathrm{pH}$ and water-holding capacity}

Subsequently, $\mathrm{pH}$ measurements were performed in triplicate on all samples 24 hours after thawing the marinated meat using a portable CRISSON $503 \mathrm{pH}$-meter equipped with a penetrating electrode probe.

In order to determine cooking losses, the samples were thawed overnight at $4{ }^{\circ} \mathrm{C}+1{ }^{\circ} \mathrm{C}$ and were thermally processed by the common dry cooking method in an electric Grill 2

Table 1. Seasoning formulations with the substitution of 25 and $50 \% \mathrm{NaCl}$ for $\mathrm{KCl}$ with the addition of herbs and spices to compose $1000 \mathrm{~g}$ of marinated meat.

\begin{tabular}{|c|c|c|c|c|c|c|}
\hline \multirow{2}{*}{$\begin{array}{l}\text { Ingredient } \\
\left(\mathrm{g} \mathrm{kg}^{-1}\right)\end{array}$} & \multicolumn{3}{|c|}{ Bovine Meat } & \multicolumn{3}{|c|}{ Chicken Meat } \\
\hline & $\mathrm{CON}$ & F25 & F50 & $\mathrm{CON}$ & F25 & F50 \\
\hline $\mathrm{NaCl}$ & 20 & 15 & 10 & 20 & 15 & 10 \\
\hline $\mathrm{KCl}$ & - & 5 & 10 & - & 5 & 10 \\
\hline Allium sativum & 2 & 2 & 2 & 2 & 2 & 2 \\
\hline Oreganum vulgare & 0.2 & 0.2 & 0.2 & - & - & - \\
\hline Bixa orellana & 1 & 1 & 1 & - & - & - \\
\hline Capsicum frutescens & 0.2 & 0.2 & 0.2 & - & - & - \\
\hline Curcuma longa & - & - & - & 1 & 1 & 1 \\
\hline Piper nigrum & - & - & - & 0.2 & 0.2 & 0.2 \\
\hline Oreganum majorana & - & - & - & 0.2 & 0.2 & 0.2 \\
\hline
\end{tabular}


Multi Britannia 127V. The samples were individually weighed on a semi-analytical electronic balance and identified. They were then grilled for about five minutes up to an internal temperature of $70^{\circ} \mathrm{C}$ and the temperature was measured using a digital thermometer (spit Incoterm), kept within the range between $-50{ }^{\circ} \mathrm{C}$ and $300{ }^{\circ} \mathrm{C}$, and a tubular stem of $145 \mathrm{~mm} \times$ $4 \mathrm{~mm}$ diameter. Next, they were cooled at room temperature and reweighed. Cooking loss was calculated by the difference between thawed and cooked weight (\% CL $=[$ (thawed weight - cooked weight)/thawed weight] $\times 100$ ).

\subsection{Texture determination and meat color}

The mechanical properties of meats were obtained using the TAXT Plus texture analyzer (Stable Micro System, Texture Technologies Corp.,UK) with $5.00 \mathrm{~kg}$ load cell capacity (shear force (SF). The analysis was performed according to the method proposed by the Meat Animal Research Center, USDA (WHEELER et al., 1997).

Each sample, weighing approximately $100 \mathrm{~g}$, was wrapped in foil and grilled in an electric grill (Multi Grill 2 Britannia 127V) at up to $70^{\circ} \mathrm{C}$, which was measured using a digital thermometer (spit Incoterm), kept within the range range between $-50{ }^{\circ} \mathrm{C}$ and $300^{\circ} \mathrm{C}$, and a tubular stem of $145 \mathrm{~mm} \times 4 \mathrm{~mm}$ diameter.

Speed reached $5.0 \mathrm{~mm} / \mathrm{sec}$, and the peak force was expressed in kgf. In both cases, six $1 \mathrm{~cm}^{2}$ samples (square cross-section), with fibers parallel to the longitudinal axis of the sample, were measured. The analyses were performed in quintuplicate.

Color measurements of the marinated products were performed after 24 -hour of storage at $5{ }^{\circ} \mathrm{C}$. For color analysis, the samples were put on the grills until internal temperature reached $70{ }^{\circ} \mathrm{C}$.

Color was measured using a portable CR10 Minolta ${ }^{\circ}$ colorimeter with integrating sphere and an illumination angle of $3^{\circ}$, i.e., a $3 / \mathrm{d}$ viewing geometry and illuminant D65. The CIE $a^{*} b^{*} L^{*}$ system (COMMISSION..., 1986) was used, and the coordinates $\mathrm{L}^{*}=$ black (0) to white (100); $\mathrm{a}^{*}=$ green $(-)$ to red $(+) ; \mathrm{b}^{*}=$ blue $(-)$ to yellow $(+)$ were measured. Color saturation rate $\left(\mathrm{C}^{\star}\right)$ and tone angle $\left(\mathrm{H}^{*}\right)$ were also determined. The average values consisted of three independent measurements taken at random across the whole meat.

\subsection{Lipid oxidation (TBARS)}

Lipid oxidation was assessed in duplicate using the 2-thiobarbituric acid (TBA) method proposed by Raharjo, Sofos and Schmidt (1992) in $5 \mathrm{~g}$ of minced raw meat (sampled from the whole minced steak free of fat, and connective tissues). Thiobarbituric Acid Reacting Substance (TBARS) rates were calculated from a standard curve and expressed as mg malonaldehyde (MDA) per kg of meat. Three marinated samples for each of the 6 treatments were used.

\subsection{Sensory analysis and cost of formulations}

A hundred untrained consumers participated in this study. Before each evaluation session, the consumers were asked to fill in a form with their personal information (gender, age, and occupation) and were given instructions and the test was continuously monitored to ensure it was being carried out properly. Each consumer was presented with three samples, one per treatment for each kind of meat, which were served and tasted in random order (MACFIE et al., 1989). The consumers were instructed to eat a piece of bread and drink mineral water at the beginning of the sensory evaluation and between samples to cleanse the palate. They evaluated overall tenderness and flavor acceptability using a 9-point structured hedonic scale anchored from 1 (dislike very much) to 9 (like very much) without the neutral central point ("neither like nor dislike") to assure consumers make a decision (FONT I FURNOLS et al., 2009).

Frozen samples were thawed for 24 hours in a chiller (0-4 ${ }^{\circ} \mathrm{C}$ ) before each session on the day of the test. Meat slices were kept at room temperature $\left(20^{\circ} \mathrm{C}\right)$ for approximately 1 hour before cooking so that the internal muscle temperature reached $13-15^{\circ} \mathrm{C}$. Cooking was performed at $200^{\circ} \mathrm{C}$ on a pre-heated double-grill hotplate (SAMMIC P8D-2) until the internal muscle temperature reached $70{ }^{\circ} \mathrm{C}$ and was monitored using a JENWAY 2000n thermocouple temperature monitoring. The samples were kept warm at $50^{\circ} \mathrm{C}$ and were provided randomly to the customers less than 10 minutes after being cooked to avoid first-over and carry-over effects (MACFIE et al., 1989).

The sensory evaluation carried out in this study was approved by the Ethics Committee in Research on Human Beings of the Universidade Estadual de Maringá, (CAAE File No. 0389-11). The panelists (consumers) signed a free and informed consent form prior to their participation in the analysis.

Product acceptability rate was calculated by the following equation proposed by Dick, Jong and Souza (2011) (Equation 1).

$\mathrm{IA}(\%)=\mathrm{A} \times 100 / \mathrm{B}$

where: $\mathrm{A}=$ average score of the product; $\mathrm{B}=$ highest score of the product.

The seasoning formulation cost (in US currency) was calculated from the cost of each individual ingredient, as provided by the suppliers.

\subsection{Statistical analysis}

Statistical analysis was carried out by analysis of variance (ANOVA) and Bonferroni (BERTOLDO et al., 2011) averaging at $5 \%$ significance level using the Statistics 7.0 software (SAS..., 2004).

\section{Results and discussion}

\subsection{Bovine meat}

In the current study, bovine meat from all treatments met the microbiological requirements for seasoned meats set by Brazilian legislation without the presence of salmonella and with a maximum coliform rate of $10^{4}$ (UFC. $\left.\mathrm{mL}^{-1}\right)$ at $45{ }^{\circ} \mathrm{C}$ (SILVA et al., 2005). Sodium reduction did not change the microbiological quality of the marinated beef, and the coliform 
rates were kept below $10^{2}$ (UFC. $\mathrm{mL}^{-1}$ ), without the presence salmonella in the meat samples of all treatments. Bidlas and Lambert (2008) reported that $\mathrm{KCl}$ might be a direct substitute for common salt in terms of antimicrobial control. Therefore, a partial or complete replacement of $\mathrm{NaCl}$ with $\mathrm{KCl}$ is feasible without any changes in the meat microbiological quality.

Moisture, ash, protein, and fat levels of meat did not change in all treatments (Table 2), and their levels of were within those recommended for bovine meat (TORRES et al., 1998). The replacement of sodium with potassium in the marinated meat reduced $(\mathrm{p}<0.05)$ the sodium level and increased the potassium level in the samples. Sodium level was reduced by $47.5 \%$ in Longissimus muscle and $45.1 \%$ in Quadriceps femoris muscle in the treatment with the F50 treatment sample. Potassium level increased with the replacement of sodium with potassium in the marinated meats. Carraro et al. (2012) observed a reduction in the sodium level (31\%) with a 50\% sodium replacement with potassium in sausages when herbs and spices were added.

Meat color was similar for all samples tested with regard to lightness $\left(\mathrm{L}^{*}\right)$, redness $\left(\mathrm{a}^{*}\right)$, and yellowness $\left(\mathrm{b}^{*}\right)$, except for a reduction in the $\mathrm{L}^{*}$ rates of Longissimus, when $50 \%$ of sodium were replaced with potassium. The average value of the parameter $\mathrm{L}^{*}$ was 45 , and therefore it is within the normal range of cooked beef (PAGE; WULF; SCHWOTZER, 2001).

Cooking did not affect water loss (approximately $30 \%$ ) for these two cuts. In fact, the values available in the literature shows water loss between 25 and 30\% of beef (TORRES et al., 1998; TOBIN et al., 2012; ANDRADE et al., 2010).

Table 3 shows color, cooking loss, $\mathrm{pH}$, shear force, and TBARS rate of the beef samples evaluated. A significant difference between the treatments was observed only for the texture of Quadriceps femoris, probably due to the veal nerves, similar to what occurred with regard to the color of Longissimus. Although the rates were different, these parameters were within the normal range, i.e., the rates were below $6.0 \mathrm{Kgf.cm}^{2-1}$ for the beef shear and between 42 and 42.9 for beef brightness according to Page, Wulf and Schwotzer (2001).

Table 4 shows no difference $(\mathrm{p}<0.05)$ between Quadriceps femoris and Longissimus samples in terms of overall acceptance. The panel consisted of 55\% females and $45 \%$ males, among whom $25.0 \%$ were less than 30 years old, $31.3 \%$ between 31 and 44 years old, $21.3 \%$ between 45 and 59 years old; and $22.4 \%$

Table 2. Chemical analysis of marinated beef.

\begin{tabular}{|c|c|c|c|c|c|c|}
\hline \multirow{2}{*}{ Item } & \multicolumn{3}{|c|}{ Quadriceps femoris } & \multicolumn{3}{|c|}{ Longissumus Muscle } \\
\hline & $\mathrm{CON}$ & $\mathrm{F} 25$ & F50 & $\mathrm{CON}$ & $\mathrm{F} 25$ & $\mathrm{~F} 50$ \\
\hline Moisture (\%) & $74.47^{a} \pm 0.53$ & $75.26^{a} \pm 0.09$ & $74.50^{\mathrm{a}} \pm 0.07$ & $72.02^{\mathrm{A}} \pm 0.37$ & $71.43^{\mathrm{A}} \pm 0.82$ & $71.68^{\mathrm{A}} \pm 0.28$ \\
\hline Ashes (\%) & $1.99^{\mathrm{a}} \pm 0.27$ & $2.38^{\mathrm{a}} \pm 0.31$ & $2.46^{\mathrm{a}} \pm 0.43$ & $2.26^{\mathrm{A} \pm} 0.12$ & $2.66^{\mathrm{A}} \pm 0.15$ & $2.17^{\mathrm{A} \pm} 0.27$ \\
\hline Crude protein (\%) & $19.33^{\mathrm{a}} \pm 0.41$ & $19.53^{\mathrm{a}} \pm 0.11$ & $20.27^{\mathrm{a}} \pm 0.21$ & $21.63^{\mathrm{A}} \pm 0.33$ & $21.03^{\mathrm{A}} \pm 0.80$ & $21.91^{\mathrm{A}} \pm 0.26$ \\
\hline Total fat (\%) & $3.78^{\mathrm{a}} \pm 0.23$ & $4.12^{\mathrm{a}} \pm 0.15$ & $3.41^{\mathrm{a}} \pm 0.63$ & $1.76^{\mathrm{A}} \pm 0.21$ & $1.72^{\mathrm{A}} \pm 0.28$ & $1.69^{\mathrm{A}} \pm 0.28$ \\
\hline Sodium (mg.100g $\mathrm{g}^{-1}$ ) & $662.13^{\mathrm{a}} \pm 1.85$ & $528.18^{\mathrm{b}} \pm 4.90$ & $363.20^{c \pm} 3.13$ & $765.10^{A} \pm 9.63$ & $678.20^{\mathrm{B}} \pm 11.55$ & $401.62^{\mathrm{C}} \pm 0.47$ \\
\hline Potassium (mg.100g $\left.{ }^{-1}\right)$ & $368.60^{c} \pm 19.14$ & $474.29^{\mathrm{b}} \pm 29.28$ & $707.74^{\mathrm{a}} \pm 7.47$ & $421.79^{\mathrm{C}} \pm 16.72$ & $594.03^{\mathrm{B}} \pm 10.99$ & $744.47^{\mathrm{A}} \pm 27.22$ \\
\hline
\end{tabular}

Means followed by different letters on the same line for each meat are different $(\mathrm{p}<0.05)$.

Table 3. Color $\left(\mathrm{L}^{*}, \mathrm{a}^{*}\right.$, and $\left.\mathrm{b}^{*}\right)$, cooking loss $(\mathrm{CL}), \mathrm{pH}$, shear force (WBSF), and TBARS (mg malonaldehyde/kg of meat) of marinated beef.

\begin{tabular}{|c|c|c|c|c|c|c|}
\hline \multirow{2}{*}{ Item } & \multicolumn{3}{|c|}{ Quadriceps femoris } & \multicolumn{3}{|c|}{ Longissimus muscle } \\
\hline & $\mathrm{CON}$ & F25 & F50 & $\mathrm{CON}$ & F25 & F50 \\
\hline $\mathrm{L}^{*}$ & $42.82^{\mathrm{a}} \pm 6.43$ & $45.00^{\mathrm{a}} \pm 4.69$ & $46.84^{\mathrm{a}} \pm 4.68$ & $48.30^{\mathrm{A}} \pm 1.48$ & $49.29^{\mathrm{A}} \pm 1.36$ & $42.32^{\mathrm{B}} \pm 2.47$ \\
\hline$a^{*}$ & $7.92^{\mathrm{a}} \pm 1.28$ & $7.55^{\mathrm{a}} \pm 0.67$ & $7.02^{\mathrm{a}} \pm 2.39$ & $8.24^{\mathrm{A}} \pm 0.65$ & $7.36^{\mathrm{A}} \pm 0.27$ & $8.42^{\mathrm{A}} \pm 1.66$ \\
\hline$b^{*}$ & $16.54^{\mathrm{a}} \pm 1.55$ & $13.65^{\mathrm{a}} \pm 1.86$ & $17.32^{\mathrm{a}} \pm 2.18$ & $16.53^{A} \pm 0.48$ & $17.05^{\mathrm{A}} \pm 0.71$ & $17.58^{\mathrm{A}} \pm 0.55$ \\
\hline LC (\%) & $34.23^{\mathrm{a}} \pm 1.88$ & $31.19^{\mathrm{a}} \pm 6.08$ & $32.80^{\mathrm{a}} \pm 0.24$ & $27.11^{\mathrm{A}} \pm 2.78$ & $34.34^{\mathrm{A}} \pm 1.66$ & $20.82^{\mathrm{A}} \pm 3.95$ \\
\hline $\mathrm{pH}$ & $5.50^{\mathrm{a}} \pm 0.02$ & $5.54^{\mathrm{a}} \pm 0.13$ & $5.66^{a} \pm 0.15$ & $5.07^{\mathrm{A}} \pm 0.10$ & $5.14^{\mathrm{A}} \pm 0.07$ & $5.68^{\mathrm{A}} \pm 0.25$ \\
\hline WBSF (Kgf) & $2.86^{\mathrm{b}} \pm 0.17$ & $2.77^{\mathrm{b}} \pm 0.55$ & $3.79^{\mathrm{a}} \pm 0.51$ & $4.44^{\mathrm{A}} \pm 0.24$ & $4.55^{\mathrm{A}} \pm 0.35$ & $4.53^{\mathrm{A}} \pm 0.23$ \\
\hline TBARS & $0.054^{\mathrm{a}} \pm 0$ & $0.048^{\mathrm{a}} \pm 0.02$ & $0.044^{\mathrm{a}} \pm 0$ & $0.042^{\mathrm{A}} \pm 0.02$ & $0.053^{\mathrm{A}} \pm 0.03$ & $0.046^{\mathrm{A}} \pm 0.04$ \\
\hline
\end{tabular}

Means followed by different letters on the same line for each meat are different $(\mathrm{p}<0.05)$.

Table 4. Sensory analysis of marinated beef with sodium reduction.

\begin{tabular}{|c|c|c|c|c|c|c|}
\hline & \multicolumn{3}{|c|}{ Quadriceps femoris } & \multicolumn{3}{|c|}{ Longissimus muscle } \\
\hline & $\mathrm{CON}^{1}$ & $\mathrm{~F} 25^{2}$ & $\mathrm{~F} 50^{3}$ & $\mathrm{CON}^{1}$ & $\mathrm{~F} 25^{2}$ & $\mathrm{~F} 50^{3}$ \\
\hline Smell & $6.86^{\mathrm{a}} \pm 1.62$ & $6.96^{\mathrm{a}} \pm 1.61$ & $6.94^{\mathrm{a}} \pm 1.31$ & $6.28^{\mathrm{A}} \pm 1.82$ & $6.54^{\mathrm{A}} \pm 1.66$ & $5.78^{\mathrm{A}} \pm 1.79$ \\
\hline Taste & $7.16^{\mathrm{a}} \pm 1.34$ & $7.24^{\mathrm{a}} \pm 1.43$ & $7.28^{\mathrm{a}} \pm 1.40$ & $6.02^{\mathrm{A}} \pm 1.59$ & $6.14^{\mathrm{A}} \pm 1.71$ & $5.46^{\mathrm{A}} \pm 2.05$ \\
\hline Color & $6.72^{\mathrm{a}} \pm 1.34$ & $6.86^{\mathrm{a}} \pm 1.47$ & $6.96^{\mathrm{a}} \pm 1.14$ & $6.46^{\mathrm{A}} \pm 1.56$ & $6.54^{\mathrm{A}} \pm 1.68$ & $5.86^{\mathrm{A}} \pm 1.76$ \\
\hline Texture & $7.50^{\mathrm{a}} \pm 1.38$ & $7.46^{\mathrm{a}} \pm 1.38$ & $7.18^{a} \pm 1.61$ & $5.26^{\mathrm{A}} \pm 1.95$ & $5.66^{\mathrm{A}} \pm 2.02$ & $5.06^{\mathrm{A} \pm} 2.11$ \\
\hline Overall acceptance & $7.38^{\mathrm{a}} \pm 1.08$ & $7.38^{\mathrm{a}} \pm 1.14$ & $7.18^{\mathrm{a}} \pm 1.17$ & $5.76^{\mathrm{A}} \pm 1.62$ & $6.18^{\mathrm{A}} \pm 1.62$ & $5.72^{\mathrm{A}} \pm 1.86$ \\
\hline I.A. ${ }^{4}$ & $82 \%$ & $82 \%$ & $80 \%$ & $72 \% /$ & $77 \% /$ & $71 \%$ \\
\hline
\end{tabular}

Means followed by different letters on the same line for each meat are different $(\mathrm{p}<0.05)$. I.A. = Index of product's acceptability. 
over 60 years. This indicates that the tasters did not notice any difference between the control formulation and the samples with reduced sodium. The addition of herbs and spices may have masked the bitter aftertaste left by less $\mathrm{NaCl}$ and more $\mathrm{KCl}$ in the food (ALBARRACÍN et al., 2011).

The acceptability index remained above $70 \%$ and reached $80 \%$ for Quadriceps femoris when 50\% sodium content was substituted. Results may be considered excellent and fully acceptable with regard to second sensory attributes (DUTCOSKY, 2011). According to Armenteros et al. (2009), the substitution of $\mathrm{NaCl}$ for $\mathrm{KCl}$ in cured and dry loin, at 35 and $50 \%$, failed to affect the flavor, texture, taste, and color; when $70 \%$ substitution was performed, no change occurred for all attributes, except for color. Accordingly, Katsiari et al. (1998) verified that there was no difference in the sensory attributes (appearance, texture, flavor, and overall appearance) of Kefalograviera cheese with $50 \%$ substitution of $\mathrm{NaCl}$ for $\mathrm{KCl}$. A study by Tobin et al. (2012) on beef hamburgers reported the same good acceptability at $50 \%$ reduction of sodium content when compared to that of commercial products available in Ireland and the UK.

\subsection{Chicken meat}

The current study shows that all treatments met the microbiological requirements for marinated beef and chicken meat set by Brazilian legislation (absence of Salmonella and maximum value of coliforms of $10^{4}$ at $45^{\circ} \mathrm{C}$ ). The results indicate that reduction in sodium did not affect the microbiological quality of the marinated chicken meat since the rates of coliforms were kept below $10^{2}$ (UFC. $\mathrm{mL}^{-1}$ ) and salmonella was absent from all treatments.
Table 5 shows the physicochemical characteristics of the marinated chicken meat samples evaluated with reduced sodium. There was no statistical difference between the samples in terms of moisture, ash, protein, and lipid in all treatments. A research on chicken burgers and condiments conducted by Torres et al. (1998) indicated $70 \%$ and $2.78 \%$ for average moisture and ash, respectively. The rates were close to those in current study.

Samples showed statistical differences $(\mathrm{p}<0.05)$ in sodium and potassium levels between control and F50 for the two chicken cuts. There was a significant reduction in sodium rates between samples, or rather, 51.06\% reduction for chicken drumstick and $50.71 \%$ for chicken breast fillet, between control and F50, while potassium levels increased proportionally between samples, confirming the substitution. This amounts to more than $50 \%$ reduction due to the addition of herbs and spices for seasoning, which corresponds to $17 \%$ of total composition, since the composition of the added ingredients (Allium sativum, Oreganum majorana, Curcuma longa, Piper nigrum) did not contain significant sodium levels (TACO, 2011).

Table 6 shows color, loss by cooking, $\mathrm{pH}$, shear force and TBARS rates for chicken meat. Significant difference in color was observed for chicken breast fillet between treatments F25 and F50. This was probably due to the use of curcuma-longa which caused higher concentration of the yellowish color when compared to that of the curcuminas.

In a study on cuts of cooked chicken with annatto, Harder et al. (2010) found $L$ rates of 68-69 for the baked 70-74 for the chicken drumsticks cooked chicken breast, very similar values to those found in the current study. Although there was no significant difference $(\mathrm{p}<0.05)$ between the treatments for the two types of meat in terms of weight loss after cooking, chicken

Table 5. Chemical analysis of marinated chicken meat.

\begin{tabular}{|c|c|c|c|c|c|c|}
\hline \multirow{2}{*}{ Item } & \multicolumn{3}{|c|}{ Drumstick } & \multicolumn{3}{|c|}{ Chicken breast fillet } \\
\hline & $\mathrm{CON}$ & F25 & F50 & $\mathrm{CON}$ & F25 & F50 \\
\hline Moisture (\%) & $73.83^{\mathrm{a} \pm} 2.96$ & $72.76^{a} \pm 0.55$ & $72.56^{a} \pm 0.27$ & $72.74^{\mathrm{A} \pm} 0.07$ & $72.80^{A} \pm 0.05$ & $72.84^{\mathrm{A}} \pm 0.08$ \\
\hline Ash (\%) & $2.37^{\mathrm{a} \pm} 0.30$ & $2.28^{\mathrm{a}} \pm 0.14$ & $2.65^{\mathrm{a}} \pm 0.18$ & $2.64^{\mathrm{A} \pm} 0.12$ & $2.48^{\mathrm{A}} \pm 0.12$ & $2.63^{\mathrm{A}} \pm 0.14$ \\
\hline Total fat (\%) & $7.16^{\mathrm{a}} \pm 0.19$ & $7.55^{\mathrm{a}} \pm 0.07$ & $7.28^{\mathrm{a}} \pm 0.04$ & $3.03^{\mathrm{A}} \pm 0.28$ & $2.66^{\mathrm{B}} \pm 0.28$ & $2.91^{\mathrm{AC}} \pm 0.28$ \\
\hline Sodium $\left(\mathrm{mg} \cdot 100 \mathrm{~g}^{-1}\right)$ & $951.70^{\mathrm{a} \pm} 1.39$ & $634.26^{\mathrm{b}} \pm 4.78$ & $465.74^{c \pm} 1.03$ & $823.29^{\mathrm{A} \pm} 4.42$ & $643.16^{\mathrm{B}} \pm 1.47$ & $405.79^{C} \pm 4.63$ \\
\hline
\end{tabular}

Means followed by different letters on the same line for each meat are different $(\mathrm{p}<0.05)$.

Table 6. Color $\left(\mathrm{L}^{*}, \mathrm{a}^{\star}\right.$, and $\left.\mathrm{b}^{\star}\right)$, cooking loss $(\mathrm{CL}), \mathrm{pH}$, shear force (WBSF), and TBARS (mg malonaldehyde/kg of meat) of marinated chicken meat with sodium reduction.

\begin{tabular}{|c|c|c|c|c|c|c|}
\hline & \multicolumn{3}{|c|}{ Drumstick } & \multicolumn{3}{|c|}{ Chicken breast fillet } \\
\hline & $\mathrm{CON}^{1}$ & $\mathrm{~F} 25^{2}$ & $\mathrm{~F} 50^{3}$ & $\mathrm{CON}^{1}$ & F2 $25^{2}$ & $\mathrm{~F} 50^{3}$ \\
\hline $\mathrm{L}^{*}$ & $59.14^{\mathrm{a}} \pm 3.62$ & $61.27^{a} \pm 2.19$ & $62.13^{\mathrm{a}} \pm 0.80$ & $63.30^{B} \pm 6.58$ & $74.32^{\mathrm{AB}} \pm 4.15$ & $76.16^{\mathrm{A}} \pm 1.84$ \\
\hline$a^{*}$ & $3.41^{\mathrm{a}} \pm 1.63$ & $4.79^{\mathrm{a}} \pm 2.06$ & $4.19^{\mathrm{a}} \pm 1.50$ & $1.58^{\mathrm{A}} \pm 0.82$ & $1.83^{\mathrm{A}} \pm 0.23$ & $1.96^{\mathrm{A}} \pm 0.84$ \\
\hline LC (\%) & $26.21^{\mathrm{a}} \pm 8.23$ & $24.58^{\mathrm{a}} \pm 0.87$ & $21.44^{\mathrm{a}} \pm 3.33$ & $19.67^{\mathrm{A}} \pm 8.17$ & $17.09^{\mathrm{A}} \pm 2.07$ & $17.45^{\mathrm{A}} \pm 2.70$ \\
\hline $\mathrm{pH}$ & $6.14^{\mathrm{a}} \pm 0.07$ & $6.83^{a} \pm 0.23$ & $6.31^{\mathrm{a}} \pm 0.28$ & $6.10^{\mathrm{A}} \pm 0.22$ & $5.68^{\mathrm{A}} \pm 0.12$ & $5.46^{\mathrm{A}} \pm 0.38$ \\
\hline
\end{tabular}

Means followed by different letters on the same line for each meat are different $(\mathrm{p}<0.05)$. 
Table 7. Sensory analysis for marinated chicken meat with sodium reduction.

\begin{tabular}{|c|c|c|c|c|c|c|}
\hline & \multicolumn{3}{|c|}{ Drumstick } & \multicolumn{3}{|c|}{ Chicken breast fillet } \\
\hline & $\mathrm{CON}$ & F25 & F50 & $\mathrm{CON}$ & F25 & F50 \\
\hline Smell & $6.80^{a} \pm 1.69$ & $6.62^{\mathrm{a}} \pm 1.74$ & $7.00^{a} \pm 1.56$ & $6.57^{\mathrm{A}} \pm 1.66$ & $6.65^{\mathrm{A}} \pm 1.52$ & $6.80^{\mathrm{A}} \pm 1.36$ \\
\hline Taste & $7.12^{\mathrm{a}} \pm 1.69$ & $6.92^{\mathrm{a}} \pm 1.55$ & $7.05^{\mathrm{a}} \pm 1.55$ & $6.97^{\mathrm{A}} \pm 1.34$ & $7.22^{\mathrm{A}} \pm 1.51$ & $6.80^{\mathrm{A}} \pm 1.43$ \\
\hline Texture & $7.17^{\mathrm{a}} \pm 1.81$ & $7.15^{\mathrm{a}} \pm 1.68$ & $7.20^{\mathrm{a}} \pm 1.50$ & $7.32^{\mathrm{A}} \pm 1.14$ & $7.32^{\mathrm{A}} \pm 1.40$ & $6.65^{\mathrm{A} \pm} 1.67$ \\
\hline Overall scceptance & $7.05^{\mathrm{a}} \pm 1.66$ & $6.97^{\mathrm{a}} \pm 1.62$ & $7.25^{\mathrm{a}} \pm 1.25$ & $7.20^{\mathrm{A} \pm} 1.28$ & $7.20^{\mathrm{A}} \pm 1.41$ & $7.00^{\mathrm{A} \pm} 1.41$ \\
\hline
\end{tabular}

Means followed by different letters on the same line for each meat are different $(\mathrm{p}<0.05)$. I.A. = Index of product's acceptability.

drumsticks showed higher rates, perhaps due to its higher fat contents when compared to those in chicken breast fillet.

Texture rates remained stable between the treatments, i.e., between 2.55 and $3.91 \mathrm{kgf}$, very close to the results found by Devant, Anglada and Bach (2007) in chicken carcasses subjected to varying temperatures, in which a CFs values between 2.92 and $3.50 \mathrm{kgf}$ were obtained, and was also close to the findings of Faria et al. (2008), $2.63 \mathrm{kgf}$ for chicken meat.

There was no significant difference between the chicken drumstick samples for the parameters analyzed. They remained within the normal range and similar to the results found by Venturini et al. (2011), mean $\mathrm{pH}$ value of 6.47 for chicken meat used in the production of fresh sausagesto the results found by Torres et al. (1998), mean $\mathrm{pH}$ value of 6.54 for chicken hamburger with condiments, and similar to those found in the present study. TBARS rates of $1.84 \mathrm{mg}$ malonaldehyde $/ \mathrm{kg}^{-1}$ were also reported by Torres et al. (1998) after 15 days of storage of the product.

Table 7 shows that all tested samples had over $70 \%$ acceptability index. Chicken drumsticks with 50\% sodium reduction or with the substitution of $50 \% \mathrm{NaCl}$ for $\mathrm{KCl}$ were potentially accepted by the consumers, it reached $80 \%$ of acceptability, with score values above 7.0. these rates were considered optimal according to Dutcosky (2011). These results represented all attributes evaluated by the consumers who, as a rule, gave satisfactory grades.

Recently, the World Health Organization (WHO) released new guidelines suggesting that adults should consume less salt. It included a minimum amount of potassium in daily diet in an attempt to reduce the risk of heart disease and strokes, recommending that adults should consume daily less than 2 grams of sodium and at least 3.51 grams of potassium (WORLD..., 2013). These guidelines are in accordance with the aim of the current study to reduce sodium and increase potassium in marinated products with sodium and potassium levels that meet the recommendations for marinated products (WHO - World Health Organization).

\subsection{Seasoning cost}

The average cost of 100 grams of seasoning for beef and chicken were US\$ 0.20 for the control samples; US\$ 0.30 for seasonings with $25 \%$ sodium replacement the replacement with potassium; and US\$ 0.40 for seasonings with 50\% sodium replacement with potassium. Since $5 \mathrm{~kg}$ of meat may be marinated with 100 grams of seasoning, the costs are lower when the total cost of marinated meat is taken into account. In fact, marinated meat is usually sold at twice the price of fresh meat.

\section{Conclusions}

The substitution of 25 and $50 \%$ sodium chloride for potassium chloride in marinated beef and chicken meat with herbs and spices proved an effective strategy for the acceptance of these products without changing their microbiological, sensorial, physical, and chemical qualities. A reduction of $50 \%$ of sodium in these products actually maintained all characteristics of a standard commercial marinated product, which can improve consumers' health due to the reduction of sodium consumption in this type of product. The meat industry can also benefit from these findings by decreasing the sodium content of their products.

\section{Acknowledgements}

This research was funded by the Araucaria Foundation of the state of Paraná, Brazil, the National Council for Scientific and Technological Development (CNPq), and the Brazilian research supporting foundation (CAPES).

\section{References}

ALBARRACÍN, W. et al. Salt in food processing; usage and reduction: a review. International Journal of Food Science Technology, v. 46, n. 7, p. 1329-1336, 2011. http://dx.doi.org/10.1111/j.13652621.2010.02492.x

ANDRADE, P. L. et al. Qualidade da carne maturada de bovines Red Norte e Nelore. Revista Brasileira de Zootecnia, v. 39, n. 8, p. 1791 1800, 2010. http://dx.doi.org/10.1590/S1516-35982010000800023

ARMENTEROS, M. et al. Biochemical changes in dry-cured loins salted with partial replacements of $\mathrm{NaCl}$ by $\mathrm{KCl}$. Food Chemistry, v. 117 , n. 4 , p. 627-633, 2009. http://dx.doi.org/10.1016/j. foodchem.2009.04.056

ASSOCIATION OF OFFICIAL ANALYTICAL CHEMISTS - AOAC. Association of Official Analytical Chemists Inc. 16. ed. Arlington: VA. 1998.

BECK, M.; JEKLE, M.; BECKER, T. Sodium chloride-sensory, preserving and technological impact on yeast-leavened products. International Journal of Food Science and Technology, v. 47 , p. $1798-1807,2012$. http://dx.doi.org/10.1111/j.13652621.2012.03048.x 
BERTOLDO, J. G. et al. Problemas relacionados com o uso de testes de comparação de médias em artigos científicos. Biotemas, v. 21, n. 2, p. 145-153, 2011.

BIDLAS, E.; LAMBERT, R. J. W. Comparing the antimicrobial effectiveness of $\mathrm{NaCl}$ and $\mathrm{KCl}$ with a view to salt/sodium replacement. International Journal of Food Microbiology, v. 124, n. 1, p. 98-102, 2008. PMid:18423764. http://dx.doi.org/10.1016/j. ijfoodmicro.2008.02.031

BIESALSKI, H. K. Meat as a component of a healthy diet-are there any risks or benefits if meat is avoided in the diet? Meat Science, v. 70, n. 3, p. 509-524, 2005. PMid:22063749. http://dx.doi.org/10.1016/j. meatsci.2004.07.017

CARDOZO, P. W. Effects of natural plant extracts on ruminal protein degradation and fermentation profiles in continuous culture. Journal of Animal Science, v. 82, n. 11, p. 3230-3236, 2004. PMid:15542469.

CARRARO, C. I. et al. The effect of sodium reduction and the use of herbs and spices on the quality and safety of bologna sausage. Ciência e Tecnologia de Alimentos, v. 32, n. 2, p. 289-297, 2012. http://dx.doi.org/10.1590/S0101-20612012005000051

COMMISSION INTERNATIONALE DE L'ÉCLAIRAGE - CIE. Colorimetry. 2. ed. Vienna: Commission Internationale de l'Eclairage, 1986.

COOK, N. R. et al. Long term effects of dietary sodium reduction on cardiovascular disease outcomes: observational follow-up of the trials of hypertension prevention (TOHP). British Medical Journal, v. 334, n. 7599, p. 885, 2007. PMid:17449506 PMCid:PMC1857760. http://dx.doi.org/10.1136/bmj.39147.604896.55

DEVANT, M.; ANGLADA, A.; BACH, A. Effects of plant extract supplementation on rumen fermentation and metabolism in young Holstein bulls consuming high levels of concentrate. Animal Feed Science Technology, v. 137, n. 1, p. 46-57, 2007. http://dx.doi. org/10.1016/j.anifeedsci.2006.10.003

DICK, M.; JONG, E. V.; SOUZA, J. P. Análise sensorial de carne de frango pré-cozida e embalada em bandeja de cartão após aquecimento em forno micro-ondas e forno convencional. UNOPAR Científica, Ciência, Biologia e Saúde, v. 13, n. 1, p. 3944, 2011.

DUTCOSKY, S. Análise sensorial de alimentos. 3. ed. Curitiba: Editora Champagnat, 2011.

ELLIOTT, P. et al. Change in salt intake affects blood pressure of chimpanzees implications for human populations. Circulation, v. 16 , n. 14, p. 1563-1568, 2007. PMid:17785625. http://dx.doi. org/10.1161/CIRCULATIONAHA.106.675579

FARIA, P. B. et al. Qualidade da carne de marreco pequim branco (Anas Platyrhynchos platyrhynchos L. 1758) comparado a frango de corte. Ciência Agrotecnologia, v. 32, n. 1, p. 213-218, 2008. http://dx.doi. org/10.1590/S1413-70542008000100031

FONT I FURNOLS, M. et al. Acceptability of lamb fed on pasture, concentrate or combinations of both systems by European consumers. Meat Science, v. 81, n. 1, p. 196-202, 2009.

HARDER, M. N. C. et al. Coloration of cooked broiler cuts fed with annatto. Ciência e Tecnologia de Alimentos, v. 30, n. 2, p. 507-509, 2010. http://dx.doi.org/10.1590/S0101-20612010000200032

HE, F. J.; MACGREGOR, G. A. How far should salt intake be reduced? Journal of Hypertension, v. 42, n. 6, p. 10931099, 2003. PMid:14610100. http://dx.doi.org/10.1161/01. HYP.0000102864.05174.E8
HOCQUETTE, J. F. et al. Opportunities for predicting and manipulating beef quality. Meat Science, v. 92, p. 197-209, 2012. PMid:22554471. http://dx.doi.org/10.1016/j.meatsci.2012.04.007

I N T E R N A T I O N A L O R G A N I Z A T I O N F O R STANDARDIZATION - ISO-R-1443. Meat and meat products - Determination of total fat content. Method ISO R-1442. Geneva: International Organization for Standardization, 1973.

I N T E R N A T I O N A L O R G A N I Z A T I O N F O R STANDARDIZATION - ISO-R-937. Meat and meat products - Determination of nitrogen content. Method ISO R-937. Geneva: International Organization for Standardization, 1978.

I N T E R N A T I O N A L O R G A N I Z A T I N F O R STANDARDIZATION - ISO-R-1442. Meat and meat products - Determination of moisture content. Method ISO R-1442. Geneva: International Organization for Standardization, 1997.

I N T E R N A T I O N A L O R G A N I Z A T I O N F O R STANDARDIZATION - ISO-R-936. Meat and meat products - Determination of total ash content. Method ISO R-936. Geneva: International Organization for Standardization, 1998.

JIMÉNEZ-COLMENERO, F.; CARBALLO, J.; COFRADES, S. Healthier meat and meat products: their role as functional foods. Meat Science, v. 59, n. 1, p. 5-13. 2001. http://dx.doi.org/10.1016/ S0309-1740(01)00053-5

KATSIARI, M. et al. Manufacture of Kefalograviera cheese with less sodium by partial replacement of $\mathrm{NaCl}$ with $\mathrm{KCl}$. Food Chemistry, v. 61, n. 1, p. 63-70, 1998. http://dx.doi.org/10.1016/ S0308-8146(97)00113-1

LAWES, C. M. M. et al. Blood pressure and the global burden of disease 2000. Part 1: estimates of blood pressure levels. Journal of Hypertension, v. 24, n. 3, p. 413-422, 2006. PMid:16467639. http:// dx.doi.org/10.1097/01.hjh.0000199801.72563.6f

MACFIE, H. J. et al. Designs to balance the effect of order of presentation and first order carry over effect in hall tests. Journal of Sensory Studies, v. 4, n. 2, p. 129-148, 1989. http://dx.doi. org/10.1111/j.1745-459X.1989.tb00463.x

PAGE, J. K.; WULF, D. M.; SCHWOTZER, T. R. A survey of beef muscle color and pH. Journal of Animal Science, v. 79, n. 3, p. 678-687, 2001. PMid:11263828.

RAHARJO, S.; SOFOS, J. N.; SCHMIDT, G. R. Improved speed, specificity, and limit of determination of an aqueous acid extraction thiobarbituric acid-C18 method for measuring lipid peroxidation in beef. Journal of Agricultural and Food Chemistry, v. 40, n. 11, p. 2182-2185, 1992. http://dx.doi.org/10.1021/jf00023a027

SAS INSTITUTE INC. SAS/STAT ${ }^{\circledR}$ 9. 1 User’s Guide. Cary: SAS. 2004.

SILVA, N.; JUNQUEIRA, V. C. A.; SILVEIRA, N. F. A. Manual de métodos de análise microbiológica de alimentos. Campinas: Varela, 1997. PMid:9303461.

SILVA, N. et al. Manual de métodos de análise microbiológica de alimentos e da água. Campinas: Varela, 2005. 56 p.

SCOLLAN, N. et al. Innovations in beef production systems that enhance the nutritional and health value of beef lipids and their relationship with meat quality. Meat Science, v. 74, n. 1, p. 17-33, 2006. PMid:22062713. http://dx.doi.org/10.1016/j. meatsci.2006.05.002

TACO. Tabela brasileira de composição química de alimentos. 4. ed. Campinas: NEPA, 2011.

TAREK, F. T. A.; GRAHAM, A. M. Salt - More adverse effects. Lancet, v. 348, p. 250-251, 1996. http://dx.doi.org/10.1016/S01406736(96)01463-8 
TOBIN, B. D. et al. Effect of varying salt and fat levels on the sensory quality of beef patties. Meat Science, v. 91, p. 460-465, 2012. PMid:22445488. http://dx.doi.org/10.1016/j.meatsci.2012.02.032

TORRES, E. et al. Papel do sal iodado na oxidação lipídica em hambúrgueres bovino e suíno (misto) ou de frango. Ciência Tecnologia Alimentos, v. 18, n. 1, p. 49-52, 1998. http://dx.doi. org/10.1590/S0101-20611998000100011

VENTURINI, A. C. et al. Sensory and microbiological evaluation of uncured fresh chicken sausage with reduced fat content. Ciência e Tecnologia de Alimentos, v. 31, n. 3, p. 629-634, 2011. http:// dx.doi.org/10.1590/S0101-20612011000300012

WHEELER, T. L. et al. A comparison of Warner-Bratzler shear force assessment within and among institutions. Journal of Animal Science, v. 75, n. 9, p. 2423-2432, 1997.
WORLD HEALTH ORGANIZATION - WHO. WHO issues new guidance on dietary salt and potassium. Geneva: WHO, 2013. Disponível em: <http://www.who.int/mediacentre/news/ notes/2013/salt_potassium_20130131/en/index.html>. Acesso em: 27 set. 2013.

XIE, J. X. et al. The relationship between urinary cations obtained from the INTERSALT study and cerebrovascular mortality. Journal of Human Hypertension, v. 6, n. 1, p. 17-21, 1992. PMid:1583625.

ZHANG, W. et al. Improving functional value of meat products. Meat Science, v. 86, n. 1, p. 15-31, 2010. PMid:20537806. http://dx.doi. org/10.1016/j.meatsci.2010.04.018 